13 Fazel M, Stein A. UK immigration law disregards the best interests of children. Lancet 2004; 363: 1749-50.

14 Steel Z, Silove D. Science and the common good: indefinite, non-reviewable mandatory detention of asylum seekers and the research imperative. Monash Bioeth Rev 2004; 23: 93-102.

15 Bracken P, Gorst-Unsworth C. The mental state of detained asylum seekers Psychiatr Bull 1991; 15: 657-9.

16 Arnold FW, Beeks M, Fluxman J, Katona C, de Zulueta F. Unmet medical needs in detention. BMJ Rapid Response 2006;

17 Sultan A, O'Sullivan K. Psychological disturbances in asylum seekers held in Iong term detention: a participant-observer account. Med J Austr 2001; 175: 593-6.

18 Thompson M, McGorry P. Maribyrnong Detention Centre Tamil survey. In The Mental Health and Wellbeing of On Shore Asylum Seekers in Australia (eds D. Silove, Z Steel): 27-30. University of New South Wales, Psychiatry Research and Teaching Unit, 1998.

19 Steel Z, Silove D, McGorry P, Mohan P. The Tamil survey. In The Mental Health and Wellbeing of On Shore Asylum Seekers in Australia (eds D Silove, Z Steel): 13-18. University of New South Wales, Psychiatry Research and Teaching Unit, 1998

20 Mollica RF, Caspi-Yavin Y, Bollini P, Truong T, Tor S, Lavelle J. The Harvard Trauma Questionnaire. Validating a cross-cultural instrument for measuring torture, trauma and posttraumatic stress disorder in Indochinese refugees. J Nerv Ment Dis 1992; 180: 111-6.

21 Mollica RF, Wyshak G, de Marneffe D, Khoun F, Lavelle J. Indochinese versions of the Hopkins Symptom Checklist-25: a screening instrument for the psychiatric care of refugees. Am J Psychiatry 1987; 144: 497-500.
22 Beiser M, Fleming JAE. Measuring psychiatric disorder among Southeast Asian refugees. Psychol Med 1986; 16: 627-39.

23 Steel Z, Silove D, Brooks R, Momartin S, Alzuhairi B, Susljik I. Impact of immigration detention and temporary protection on the mental health of refugees. Br J Psychiatry 2006; 188: 58-64.

24 Gandek B, Ware JE, Aaronson NK, Apolone G, Bjorner JB, Brazier JE, et al Cross-validation of item selection and scoring for the SF-12 Health Survey in nine countries: results from the IQOLA Project. International Quality of Life Assessment. J Clin Epidemiol 1998; 51: 1171-8.

25 Steel Z, Momartin S, Bateman C, Hafshejani A, Silove D. Psychiatric status of asylum seeker families held for a protracted period in a remote detention centre in Australia. Aust N Z J Public Health 2004; 28: 527-36.

26 Momartin S, Steel Z, Coello M, Aroche J, Silove D, Brooks R. A comparison of the mental health of refugees with temporary versus permanent protection visas. Med J Austr 2006; 185: 357-61.

27 Goldberg DP, Williams P. A User's Guide to the General Health Questionnaire. nferNelson, 1988.

28 Mares S, Jureidini J. Psychiatric assessment of children and families in immigration detention clinical, administrative and ethical issues. Aust $\mathrm{NZJ}$ Public Health 2004; 28: 520-6.

29 First MB, Spitzer RL, Gibbon M, Williams JBW. Structured Clinical Interview for DSM-V Axis I Disorders Administration Booklet. American Psychiatric Press, 1997.

30 Kaufman J, Birmaher B, Brent D, Rao U, Flynn C, Moreci P, et al. Schedule for affective disorders and schizophrenia for school age children - present and lifetime version (K-SADS-PL): initial reliability and validity data. J Am Acad Child Adolesc Psychiatry 1997; 36: 980-8.

\section{Psychiatrists in 19th-century fiction}

\title{
The Rose and the Key (1871), J. Sheridan LeFanu
}

\section{Fiona Subotsky}

The Rose and the Key is one of Sheridan Le Fanu's sensation novels, without any supernatural elements. It is set in England rather than Ireland, for better sales.

The heroine, Maud, is deceived into entering a lunatic asylum on the pretext that she is visiting the great house of Lady Mardykes. Evidence as to Maud's insanity has been gained by a strange evangelical called Elihu Lizard, who notes her playful claims of another identity and puts this down to delusion. Her mother, Lady Vernon, testifies to a suicide threat. Two sinister doctors, Dr Malkin the local practitioner and Dr Antomarchi an asylum administrator, collude with Lady Vernon, all hoping to gain by the prevention of Maud's marriage. Dr Damian, the upright but distant owner of the asylum, approves the papers but has not seen the patient or understood the family issues. Mr Tintern, the local magistrate, also eager to keep the approval of Lady Vernon, acts to endorse the arrangement legally.

Dr Michael Antomarchi has the key medical role. Obviously, he is 'foreign' and has a striking appearance - with 'marble feature, strange eyes, and coal-black square beard.' He is an expert in mesmerism, and controls the asylum (appropriately named 'Glareswood') with his fierce gaze and stern authority. He cows Maud into compliance by making her witness a forcible shower-bath followed by an emetic, which leaves the patient nearly dead. Le Fanu steps back from the narrative here, to point out that such a case was indeed investigated by the Lunacy commission, but that now such a practice 'is no longer countenanced by the faculty'.

Antomarchi is ambitious: he hopes to take over the asylum soon, and meanwhile is prepared to take money in excess from Lady Vernon. He wants to be 'monarch of all I survey'. The same expression was later used by Henry Maudsley in his autobiographical recollection of his time as medical superintendent at Cheadle, adapting a verse by William cowper:

'I am monarch of all I survey,

I am lord of the fool and the brute,

From the centre all round to the sphere,

My rite there is none to dispute.'

Although Maudsley achieved this, as is the nature in romances the 'brilliant rogue' Antomarchi has his evil plans foiled, and is compelled to leave the country, ending in 'sore straits'. 